\title{
RE-INTERPRETING GENESIS 34 IN THE LIGHT OF RELIGIOUS VIOLENCE IN NIGERIA
}

\author{
Luke E. Ugwueye \& Ikenna L. Umeanolue \\ Nnamdi Azikiwe University, Awka, Nigeria. \\ *http://dx.doi.org/10.4314/ujah.v14i3.12
}

\section{Abstract}

Religion plays significant roles in social harmony, yet it also serves as a motivation for violence. In Nigeria, religion has been at the centre of most violent conflicts, thereby gaining notoriety as one of the prime security challenges confronting the country. Genesis 34 is an important chapter in the Old Testament Bible. It demonstrates the violence done to Dinah, the only daughter of Jacob by Shechem and also the violence done by the children of Jacob to Hamor, Shechem and the whole community. This shows the reality of violence in every nation that is made of up of various tribes and ethnic groups. The reality of violence in Nigeria is even more pronounced as the nation is made up of millions of people with many ethnic groups and with various religious affiliations. Genesis 34 also gives the causes of religious violence in both Israelite and Nigerian societies. Paramount among the causes of religious violence include religious intolerance, religious fanaticism, lack of forgiveness, poverty, unemployment, suspicion and lack of trust. In order to control religious violence in Nigeria, this paper recommends that there should be respect for one another, respect for sanctity of human life, forgiveness and rightful engagement of youths.

\section{Introduction}

Nigeria as a nation is religiously pluralistic and these religions and their adherents are often hostile to one another. Religion 
could serve as an instrument of peace and reconciliation, and indeed has served as such in many civilizations. Paradoxically, however, it has also served as a motivation for violence, hence its indication in some literature as a 'double-edged sword' (Obasi, 2009; Hitchens and Dawkins, 2011; Maregere, 2011). Over the years, religion has been at the centre of most violent conflicts in Nigeria, thereby gaining notoriety as one of the prime security challenges confronting the country. This is to say that religiously motivated violence has plagued the Nigerian nation more than any other security challenge. Indeed, the level of violence and atrocities being perpetuated with religion in Nigeria makes one to argue that religion is inherently violent. Hitchens and Dawkins (2011) argue that religions do tremendous harm to society in three ways: Thus, religions sometimes use war, violence and terrorism to promote their religious goals; religious leaders sometimes contribute to secular wars and terrorism by endorsing and supporting violence; and religious fervour is sometimes exploited by secular leaders to support war and terrorism. Corroborating the above view and perhaps as a result of several crises associated with religion in Nigeria, Soyinka in Igboin (2010) argues for the separation of religion from national affairs. For him, religion is a social variable that should be left to private practice. It has no space in politics, development and unity. Perhaps the foregoing explains the prime position that religious violence occupies on Nigeria's security pyramid.

The word 'violence' in the context of this paper is any unjust or unlawful display of force with a view of causing confusion and intimating an individual or a group of people. Oladosu's (2012) definition of violence is equally appropriate in this context. He says "violence is any deliberate act aimed at 
Re-Interpreting Genesis 34 in the Light of Religious Violence in Nigeria - Luke E. Ugwueye $(\mathrm{PhD})$ \& Ikenna L. Umeanolue

causing physical wound, psychological trauma, emotional disturbance, verbal assault, economic damage or sexual harassment to another person or group of persons" (p. 172). Therefore, religious violence is motivated by religious precepts, text or doctrines. It also includes violence against religious institutions, persons or objects. There are several causal diagnosis of religious violence in Nigeria, but much of the literature in this area pay premium attention to the underlying socio-political, economic and governance factors that precipitate religious conflicts. The thrust of this paper is to attempt a re-interpretation of Genesis 34 with a view of understanding religious violence in Nigeria, its causes and solutions. This paper adopts exegetical method of biblical interpretation which facilitates the application of genesis 34 to Nigerian society. This paper is therefore intent on objectively critiquing the negative deployment of religion as an instrument for social disharmony.

\section{Exegetical Analysis of Genesis 34}

Genesis 34 demonstrates the violence done to Dinah, the only daughter of Jacob by Shechem and also the violence done by the children of Jacob to Hamor, Shechem and the whole community. This chapter of Genesis gives insight into the causes of violence in Genesis 34. Commenting on Genesis 34, Kidner (1967) is of the opinion that in the chapter there is the price paid for disobedience by Jacob who was called to go to Bethel but he chose to stop at Shechem, a day's journey to Bethel. The price included rape, treachery and massacre, that is, a chain of evil that proceeded from unequal partnership with the Canaanite community. Writing from a feminist perspective, Scholz (1998) observes the marginalization of rape by Christian commentators on Genesis 34. She argues that rape is treated as sub-category of illegal intercourse and that is merged 
with discussions on homosexuality, bestiality or necrophilia. In other words, she is not comfortable that many biblical commentators did not mention rape in Genesis 34 or indicate any violation of Dinah.

Genesis 34 begins with the freedom which Dinah had in the family, possibly being the only daughter. The Bible says she went out to see the daughters of the land (Gen. 34:1). The Hebrew word וַת is qal imperfect third person feminine singular plus waw consecutive from $\mathbf{S}$. It means 'to go out' or 'come out' or 'to go forth' from the presence of the family. Unfortunately, instead of Dinah to see the women of the land, it was Shechem who used his position and power over her. The idea of violence begins in Genesis 34:2 when Shechem took Dinah, laid with her and violated her. Shechem was impatient as he demonstrated his so-called love to Dinah. According to Brown, Driver and Briggs (1979), the word לקסָ which means

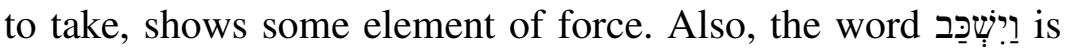
from שֵָׁכָב which means to lie down with. It is to have sexual relation with a person (Gen. 26:10; 35:22). Furthermore, the word that specifically speaks of violation of Dinah by

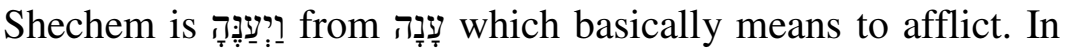
this context it means to humble, mishandle, and afflict an individual or to humble a woman by cohabitation.

Genesis 34:3 further gives clarity as to the attitude of

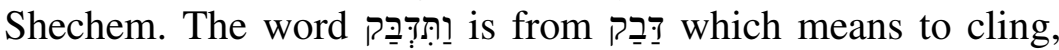
cleave or keep close as a sign of loyalty or affection. In this context, it speaks of Shechem's soul which was close to Dinah (cf. Gen. 2:24; Ruth 1:14; I Kgs 11:2). The word נֶֶֶּ means soul, living being, life, self, person, desire, appetite and emotion. In this context, it speaks of Shechem's desires and emotions for Dinah (Gen. 34:3, 8; Psalm 63;9). Even though 
Re-Interpreting Genesis 34 in the Light of Religious Violence in Nigeria - Luke E. Ugwueye $(\mathrm{PhD})$ \& Ikenna L. Umeanolue

the word which is for love is used in the passage, the sincerity of the love is questioned. It can be taken to mean lust rather than love as it expresses Shechem's interest to exert his will for sex over Dinah. This again explains why he had to speak

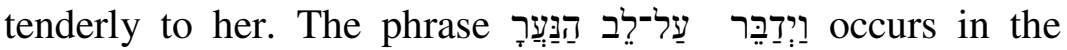
context of fear, anxiety, sin or offense.

Genesis 34:4-7 deals with the reaction of Jacob and his sons to the evil that was done to the family. On the part of Jacob, he kept quiet about it. However, the sons did not take the matter lightly. They were filled with grief and fury. The two words that are used in connection with grief and fury are עֵֵַ which means hurt, pain or grief and דָָרז which means burn or be kindled of anger. Shechem's sexual evil against Dinah was infamous; incriminating a whole community. The sons of Jacob were angry because a serious offence and disgraceful thing has been done to them by Shechem. Some other passages with such an outrageous act are Deuteronomy 22:21, Joshua 7:15, Judges 20:6, II Samuel 13:12 and Jeremiah 29:23.

Genesis 34:8-24 describes the proposal by Hamor and the deceptive sons of Jacob. Hamor, the father of Shechem made proposal for intermarriage and unrestricted movement in the land. He also offered to give them anything they asked for in the form of dowry. But, the attractive offer of Hamor and his son, Shechem were declined by the sons of Jacob on the basis of their religious stipulation and belief which forbid marriage with an uncircumcised person (Deut. 7:1-3; 17). Thus, their response that they could not give their sister to an uncircumcised man was deceptive. The Hebrew word מִּרָָזה is a feminine noun which means deceit or treachery. It is used to describe deceptive balances (Amos 8:5; Hosea 12:8; Prov. 11:1); it speaks of craftiness (II Kgs 9:23). In this context 
(Gen. 34:7), it is used of crafty speech and at other passages, it speaks of treacherous lips (Psalms 17:1; 52:6; 109:2). Therefore, the sons of Jacob deceitfully gave Hamor and his son (Shechem) the circumcision of all the males in the community as the only condition for marrying their sister. Hamor's offer is not only the Dinah-Shechem marriage, but intermarriage between the groups, with appropriate rights to settle in the land (Gens 34:8-10). According to Clifford and Murphy (1995), "Circumcision is viewed here as a mark of separation from others; it is not the covenantal sign that it came to be in the post-exilic period" (p. 35). Unfortunately, Hamor and Shechem, did not suspect the deceptive motives of Jacob's son and so they agreed to the proposal. Using their influence in the society, Hamor and Shechem went to the city to convince everyone of the need to be circumcised. Again, there is an element of deception in the information given to the members of the community by Hamor and Shechem. They informed the people that they (Shechemites) would not only intermarry with the descendants of Jacob but they will have access to their livestock, property, land and animal. This means that the whole community accepted the terms of circumcision on wrong and deceptive grounds.

Genesis 34:25-29 describes the killing and violence on the Shechemites. On the third day of circumcision, when all the men of the city who were capable of carrying arms were temporarily incapacitated as a result of pain, Simeon, Levi and their servants descended upon the city and violently killed every male. The use of the word gives the impression that the people were off their guard (Ezekiel 30:9), they slew all the males, including Hamor and Shechem. In other words, they came to the city without any resistance. Bechtel (1996) notes that: 
Re-Interpreting Genesis 34 in the Light of Religious Violence in Nigeria - Luke E. Ugwueye $(\mathrm{PhD})$ \& Ikenna L. Umeanolue

The requirement of circumcision is only a clever pretext to render the Shechemites defenceless, so they can take revenge for the shame of the pollution of their group. They retaliate by slaying, plundering and taking the strength of Shechem, Hamor and the Shechemite community (278).

They brought back their sister and plundered the whole city, carrying all the cattle in the town and in the field, and their possession, including the women and children. Writing on the seriousness of the violence, Keil (1981) notes that, "The abrupt way in which the plundering is linked on to the slaughter of all males, without any copulative way, gives to the account the character of the indignation at so a revolting crime; and this is also shown in the verbosity of the description" (341).

Corroborating the above statement, though from another perspective, Bechtel (1996) enunciates that:

Ironically, if there is a rape in this story, it is Simeon and Levi who 'raped' the Shechemites. It is their behaviour that is violent and hostile, carried out for the purpose of exploitation. It creates the illusion of dominance, control and superiority, in order to silence their feelings of vulnerability and inferiority (278).

The fact that Jacob was not comfortable with the action of his children is reflected on what he said to Simeon and Levi, the actual perpetrators of the violence on his dead bed. According to Genesis 49:5-7:

Simeon and Levi are brothers; their swords are weapons of violence. Let me not enter their council, let me not join their assembly for they have killed men in their anger and hamstrung oxen as they pleased. Cursed 
be their anger, so fierce and their fury so cruel! I will scatter them in Jacob and disperse them in Israel.

Even though there may be justification for their action on the basis of their religion but the level of the violence done on the Shechemites is condemnable. Commenting on this, Keil (1981) enunciates that, "The deception they practiced, the abuse of the covenant sign of circumcision as a means of gratifying their revenge, and the extension of that revenge to the whole town, together with the plundering of the slain, were crimes deserving of the strongest reprobation" (315). The above analysis of Genesis 34 is what Clarke (1953) describes as "The massacre at Shechem" (p. 353). Thus, the people of Shechem were killed violently when they could not defend themselves.

\section{Religious Violence and Activities of Boko Haram in Nigeria} Several people have written and catalogued on religious violence in Nigeria. Our focus at this point is not to recapitulate all that have been said or written but to identify and highlight the activities of the Boko Haram group. Etmologically, Boko Haram comes from the Hausa word 'Boko' which means 'Western or non-Islamic education' and the Arabic word 'Haram' which means 'sin'. So, Boko Haram means 'Western or non-Islamic education is a sin'. Boko Haram is a controversial Nigerian militant group that seeks the imposition of Sharia law in Nigeria especially in the northerrn states of the country (Ogunkunle, 2011).

According to Kuniyi-Cole (2010):

The Boko Haram group was founded in 2002 in Maiduguri by Mohammed Yusuf who was hostile to democracy and secular education system. In 2004, he moved to Kanamma, Yobe State where he set up a base 
Re-Interpreting Genesis 34 in the Light of Religious Violence in Nigeria - Luke E. Ugwueye (PhD) \& Ikenna L. Umeanolue

called 'Afghanistan'. The membership of the group includes people from neighbouring Chad and they speak only Arabic. They refused to mix with local people and they seem to have a grudge against other Muslims who do not belong to them (18).

Initially, the Boko Haram group started their attack on police outposts, by killing police officers. On September 7, 2010, the group broke into a prison in Bauchi State and set free over 700 inmates. In December, 2010, members of Boko Haram were blamed for a market bombing in Maiduguri, following which 72 of its members were arrested by the combined military and police operation. The leader of the group, Mohammed Yusuf, was also killed in the operation. In January 2011, the group struck in Borno State, killing 4 people in Dala Alemederi ward in Maiduguri metropolis.

Commenting on the activities of Boko Haram group in Borno State, Adaji (2011) says:

Maiduduri, the capital of Borno State, North-East Nigeria, has not known peace since July 2010, exactly one year after the leader of Boko Haram Islamic sect, Mohammed Yusuf and hundreds of his followers were killed by a combined military and police operation. The city, indeed, the state, has come under intensive attack by unidentified gunmen who go about killing innocent civilians, traditional rulers, religious leaders and security men, putting the citizens in perpetual fear (1819).

Explaining further the reason why the group has targeted some selected groups of people for killing, he says: 
The killing of traditional rulers was in retaliation for the role they played in 2010. The royal fathers allegedly provided information to security agencies, which led to the arrest and killing of members of the group. The sect also sees security agents, especially the police and soldiers, as enemies because they carried out the killing of the leaders and members of the group during the onslaught, while the group is bitter with religious leaders for opposing their struggle by preaching against their activities instead of supporting their cause, which they claim is to get rid of corrupt leaders (19).

In view of the perennial religious tensions in Nigeria, there has been a sustained culture of mutual suspicion and unhealthy rivalry between the two dominant religious groups (Christianity and Islam). The introduction of section 38(1) and 10 into the Nigerian Constitution, which have guaranteed freedom of religion and prohibited the declaration of state religion respectively, has done little to attenuate the frequency of religious conflicts. Thus conflicts between Nigerian Christians and Muslims have often manifested in violent interreligious violence.

\section{Causes of Religious Violence in Nigeria in the Light of Genesis 34}

There are several causes of religious violence in Nigeria. Some of them are highlighted here in the light of Genesis 34. One of the causes of religious violence in Nigeria is religious intolerance. This is inability of adherents of a religious group to stomach the weaknesses of the other group. This is one of the main causes of religious violence in Nigeria. Such intolerance often leads to tension, misunderstanding, hostility 
Re-Interpreting Genesis 34 in the Light of Religious Violence in Nigeria - Luke E. Ugwueye $(\mathrm{PhD})$ \& Ikenna L. Umeanolue

and then confrontation. In Genesis 34, Jacob's children exhibited religious intolerance towards the Shechemites. This religious intolerance is also observed in the activities of members of Boko Haram who are always hostile to nonMuslim citizens of Nigeria.

Closely connected with intolerance is religious fanaticism which is the belief that one religion is the best and so the adherents of other religions must be dealt with and eradicated. Commenting on the people involved in religious fanaticism, Isiramen (2010) notes that:

People take up arms against fellow citizens only on the premise that they loathe them for embracing religions other than their own. Blinded to the ideals of other religions, these fanatics ignore the provisions of the Constitution and warm themselves up with the aim of establishing a theocratic state (333).

Unfortunately, there has been an increase in religious fanaticism in Nigeria. An example is Boko Haram whose members are ready to wage war against those who have contrary beliefs. The group seems to have no regards for fundamental human rights which guarantee freedom of worship for every citizen.

It is unfortunate to note that the level of poverty in Nigeria has led to all forms of social vices connected with religious violence. Closely associated with poverty is the high rate of unemployment which perhaps has contributed greatly to religious violence in Nigeria. There are many cases of welleducated and hardworking youths who have graduated from various universities and other tertiary institutions for years and yet, have no job. Therefore, it becomes easy for selfish 
members of the political and elite class to make of the services of these youths to cause religious violence even with reward.

Lack of forgiveness is another major cause of religious violence in Nigeria. In other words, whenever an offence is committed by the adherents of one major religion, the adherents of the other religion make sure that revenge is taken. For example, there were more than 1000 people that died between February and May 2000 in the Northern part of the country. This act led to a reprisal attacks in the south-eastern states where hundreds of ethnic Hausa were killed. Also, the killing of several hundreds of Muslims in 2004 in a small town of Yelwa in Plateau State snowball to Kano where several people were killed in a reprisal attack by Muslims.

Suspicion and lack of trust among the adherents of major religions in Nigeria is another cause of religious violence in the nation. According to Isiramen (2010), the origin of suspicion as a cause of religious violence in Nigeria started at the time of General Ibrahim Babangida when he enlisted Nigeria into the Organization of Islamic Countries (OIC) in 1986. This action led to serious criticism especially among the non-Muslims as they were not comfortable with the whole process. The level of suspicion and animosity that exist among the adherents of religious groups shows how volatile religious matters are in Nigeria.. Commenting on the suspicion between the Christians and Muslims in Nigeria, Ehioghae (2010) says that as long as suspicion dominate Christian-Muslim relations in Nigeria, religious crises are bound to remain destabilizing factor in Nigeria and her development. 
Re-Interpreting Genesis 34 in the Light of Religious Violence in Nigeria - Luke E. Ugwueye (PhD) \& Ikenna L. Umeanolue

\section{Solutions to Religious Violence in Nigeria}

Genesis 34 shows the reality of violence in every nation that is made up of various tribes and ethnic groups. Jacob and his children came to a new environment and the simple step taken by his daughter, Dinah led to various forms of violence as seen in the paper. The reality of violence in Nigeria is even much more pronounced as the nation is made up of over 140 million people with many ethnic groups and with various religious affiliations. Therefore, the following solutions will go a long way to control religious violence in Nigeria.

Various religions in Nigeria and their adherents should have respect for one another's views. There are inter-faith diversities in the three broad forms of African Traditional Religion, Christianity and Islam. There is the need to acknowledge these differences. To do so, effort needs to be made to understand one another and what each group stands for. It is necessary for the adherents of these different religions in Nigeria to open their hearts to the way of life of others so as to understand him or her better. More needs to be done along these lines. It is only when we respect one another in our differences that peace can be ensured. Respect does not mean that we accept what the other believes or says. But it certainly means that we respect his freedom to follow whatever religion he proposes for himself. This respect is far more than what people often call tolerance. The concept of tolerance is negative in this regard. You tolerate what you do not like but about which you cannot do much. In addition, Section 38 (1) of the 1999 Constitution of the Federal Republic of Nigeria states:

Every person shall be entitled to freedom of thought, conscience and religion, including freedom to change his religion or belief and freedom either alone or in 
community with others and in public or in private, to manifest and propagate this religion or belief in worship, teaching, practice and observance.

The above legal provision is made in order to ensure that citizens enjoy religious freedom and that the state or government does not affiliate itself or show preference for one religion (Umeanolue \& Mgbemena, 2011).

Obviously, respect for one another is lacking in Genesis 34 and that was why Shechem violated Dinah and thereafter Simeon, Levi and others violated the whole community. The Boko Haram group in Nigeria seems to lack respect for other religious groups and the entire citizens, even in spite of Constitutional provision for freedom of religion. Respect for one another's faith must be taken seriously so as to curb religious violence in Nigeria. Adherents of various religions must live out the virtues of religion which should bear the spirit of respect, love, peace, perseverance and understanding.

Another solution to religious violence in Nigeria is Forgiveness and adoption of non-violent option: This is a panacea to religious violence. The children of Jacob could not forgive the Shechemites for the evil done to their sister and so they reacted violently. Lack of forgiveness is also lacking in the action of Boko Haram sect whose activities have become much violent since the killing of their members in 2010. Resolving conflict generally by violence is no longer acceptable today since the extent and intensity of the violence can no longer be calculated and it may result in the destruction of whole spheres of life (Oyeshola, 2005). We must learn to forgive and avoid non-violent option for the sake of peace in our nation. The early Christians adopted this method and their 
Re-Interpreting Genesis 34 in the Light of Religious Violence in Nigeria - Luke E. Ugwueye (PhD) \& Ikenna L. Umeanolue

faith was spoken of throughout the world (Rom. 1:8). They conquered by rewarding evil with good. Furthermore, the injunction of Apostle Paul in Romans 12:17-21 is vital:

Do not repay anyone evil for evil. Be careful to do what is right in the eyes of everybody. If it is possible, as far as it depends on you, live at peace with everyone. Do not take revenge, my friends, but leave room for God's wrath, for it is written: "It is mine to revenge; I will repay", says the Lord. On the contrary: "If your enemy is hungry, feed him; if he is thirsty, give him something to drink. In doing this, you will heap burning coals on his head.

Furthermore, there should be respect for sanctity of human life. The Bible attaches so much importance to the life of human beings. Exodus 20:13 says "You shall not murder". Also Genesis 1:27 says that God created man in his own image. This means that no man has any right to take the life of another in the name of religion. Indeed, what Simeon, Levi and the brothers did to the Shechemites was wrong. In the same vein, the act of killing innocent citizens in the name of religion as demonstrated by the Boko Haram sect is bad and evil. Obviously, when everyone is conscious of the sanctity of human life and due respect is given to life; the deadly religious crises that are being experienced from time to time will be greatly reduced.

Rightful engagement of youths is also very important in curbing religious violence in Nigeria. The fact that young people are strong is established in the Bible (Prov. 20:29). Also, God's plan for youths is to see visions (Joel 2:28) and consequently become useful in life. The situation where youths are used to cause religious violence similar to what Simeon 
and his brothers did to the Shechemites is bad and should be discouraged. Therefore, efforts should be made at all levels of government (Local, State and Federal) to take care of the teeming population of the youths in the society who are poor and unemployed. In other words, the government must address decisively the issues of unemployment, hunger and poverty. A situation where young people are unemployed, hungry and poor even after the university or tertiary education is not good for the nation. Perhaps, Dinah became an object of violence in the hand of Shechem as a result of her idleness (Ogunkunle, 2011). This justifies the saying that 'an idle body is a devil's worshop'.

For the above solutions and recommendations to work, there is need for all stakeholders to re-examine our approach to conflict resolution. Ikpaat (2013) has correctly identified three approaches. These include the traditional approach whereby the government official, traditional and religious leaders are engaged in conflict resolution; the process-oriented approach which involves politicians, academics, opinion leaders, press, students and internet writers; and the polylectic approach which is an amalgamation of both traditional and processoriented approaches. We align ourselves with the third approach, the polylectic approach which is a comprehensive method of conflict resolution. It is a method which gets all the stakeholders involved in the process of conflict resolution. This approach is reasonable because it is regulated but independent, result oriented, representative of affected parties, and consensus building. Furthermore, since it works out details of a sound model, it gives the government a clear policy direction to follow. In this approach, government agents, traditional rulers, religious leaders, academics, politicians, NGOs, professionals in Conflict Resolution, psychologists, 
Re-Interpreting Genesis 34 in the Light of Religious Violence in Nigeria - Luke E. Ugwueye $(\mathrm{PhD})$ \& Ikenna L. Umeanolue

students and other necessary members from Consultative Groups mandated to study details of religious conflicts and create workable models of conflict prevention and resolution for universal applications.

\section{Conclusion}

This study of genesis 34 in its relation to the contemporary Nigerian society has shown that religion which is meant to give hope to its adherents has become a source of violence. Also, the paper has shown that the common features of violence, either in Genesis 34 or in the Nigerian society are deception, anger, unforgiveness and vengeance. Obviously, violence in any form, especially religious violence should be discouraged for the sake of peace and development of our nation, Nigeria. Therefore, efforts must be made by all stakeholders - individuals, organisations, religious bodies, government at all levels, among others to see that there is a lasting solution to the recurring decimal of religious violence in Nigeria through respect for one another, forgiveness, sanctity of human life and rightful engagement of youths.

\section{References}

Adaji, B. (2011). Blood-thirsty Boko Haram. The News. Vol. 36. No. 66. 14-21.

Bechtel, L. M. (1996). What if Dinah is not raped? (Genesis 34). In J. W. Rogerson (Ed.). The

Pentateuch: The biblical seminar 39 (pp. 272-285). Sheffield: Sheffield academic. 
Brown, F., Driver, S. R. \& Briggs, C. A. (1979). Genesis. In A. Brenner (Ed.). The new Brown-

Driver-Briggs gesenius: Hebrew and English companion to the Bible ( $2^{\text {nd }}$ series) (pp. 537-548). Massachusetts: Hendrickson.

Clarke, W. K. L. (1953). Concise Bible commentary. New York: The Macmillan.

Clifford, R. J. \& Murphy, R. E. (1995). Genesis. In R. E. Brown, J. A. Fitzmyer \& R. E. Murphy

(Eds.). The new Jerome biblical commentary (pp. 843). New Delhi: Indira.

Ehioghae, E. N. (2010). Curbing religious violence in a pluralistic society: A Christian

perspective. In R. A. Akanmidu et al (Eds.). Religion and democracy in the $21^{\text {st }}$ century (pp. 26-32). Ilorin: Decency.

Hitchens, C. \& Dawkins, R. (2011). Religion and violence. Retrieved February 15, 2013 from

http//:en.wikipedia.org.

Igbion, B. O. (2013). Religion, politics and the Nigerian nation. In C. O. Isiramen et al (Eds.).

Religion and the Nigerian nation: Some topical issues (pp. 113-117). Ibadan: En-Joy.

Ikpaat, C. (2013). Religion, conflict prevention and revolution: A multi-dimensional approach. 
Re-Interpreting Genesis 34 in the Light of Religious Violence in Nigeria - Luke E. Ugwueye $(\mathrm{PhD})$ \& Ikenna L. Umeanolue

Retrieved $\quad$ February $\quad 15, \quad 2013$ fromhttp://www.nigerdeltacongress.com/rarticles/religi on_conflict_prevention_and.htm.

Isiramen, C. O. (2010). Religious crises and development in Nigeria. In C. O. Isiramen et al

(Eds.). Religion and the Nigerian nation: Some topical issues (pp. 327-333). Ibadan: En-Joy.

Keil, C. F. \& Delitzsh, F. (1981). Commentary on the Old Testament in ten volumes (Vol. 1):

The Pentateuch. Grand Rapids: William B. Eerdmans.

Kidner, D. (1967). Genesis: An introduction and commentary. Leicester: Inter-versity.

Madu, J. E. (2003). The paradox of the "one" and the "many" in religion. Nkpor:

Globe Communications.

Maregere, T. P. (2011). Religion: A source of conflict and a resource for peace. Conflict Trends

Issue. 1. 2011. 17-23.

Merriam, W. (Ed.) (1980). Encyclopedia of religion. New York: Prentice Hall.

Obasi, C. O. (2009). The role of religion on issues of conflict and peace. In M. Ikejiani-Clarke

(Ed.). Peace studies and conflict resolution in Nigeria: $A$ reader. Ibadan: Spectrum

Books. 
Ogunkunle, C. O. (2011). An exegetical study of Genesis 34 within the context of religion and violence in Nigeria. In R. A. Akanmidu (Ed.). Thoughts in the humanities (pp. 385-402). Ilorin: Decency.

Oladosu, A. G. (2011). The role of religion in preventing electoral violence. Retrieved March 12,

2013 from http://www.google.com.ng.

Oyeshola, D. (2005). Conflict and context of conflict resolution. Ile-Ife: Obafemi Awolowo

University.

Scholz, S. (1998). Through whose eyes? Aright reading of Genesis 34. In A. Brenner (Ed.).

Genesis: A feminist companion to the Bible (2nd series). Sheffield: Shelffield Academic.

The Federal Republic of Nigeria (199). The Constitution of the Federal Republic of Nigeria.

Section 38 (1).

Umeanolue, I. L. \& Mgbemena, S. C. (2011). Religion as a factor in post-independence Nigerian

politics: The implications for national development. In A. B. C. Chiegboka et al (Eds.). The humanities and sustainable development (pp. 419-429). Nimo: Rex Charles \& Patrick. 